\title{
Influence of Root Pruning on Stem and Root Morphology of Poplar (Populus deltoides) Clones
}

\author{
Neeta Shweta Kerketta*, Afaq Majid Wani, Sameer Daniel and Hemant Kumar \\ College of Forestry, Sam Higginbottom University of Agriculture, Technology and Sciences \\ (SHUATS), Allahabad-(211007), Uttar Pradesh, India \\ *Corresponding author
}

\begin{tabular}{|c|c|}
\hline & A B S T R A C T \\
\hline $\begin{array}{l}\text { Populus deltoids, } \\
\text { Root pruning, } \\
\text { Survival percentage, } \\
\text { Vegetative growth. }\end{array}$ & \multirow{3}{*}{$\begin{array}{l}\text { The aim of the study was to determine the influence of root pruning on the above and } \\
\text { below ground vegetative growth of poplar (Populus deltoides) clones viz., } \mathrm{S}_{7} \mathrm{C}_{15} \text { and Uday } \\
\text { in } 2012-13 \text { at College of Forestry, SHUATS, Allahabad (U.P). The experiment involved a } \\
\text { factorial randomized block design which had five treatments }\left(\mathrm{P}_{1}-\text { Control (un-pruned }\right. \\
\text { roots), } \mathrm{P}_{2} \text { - root pruned at } 5 \mathrm{~cm}, \mathrm{P}_{3} \text { - root pruned at } 10 \mathrm{~cm}, \mathrm{P}_{4}-\text { root pruned at } 15 \mathrm{~cm} \text { and } \mathrm{P}_{5}- \\
\text { root pruned at } 20 \mathrm{~cm} \text { ) with three replications and each treatment consisted of } 10 \text { plants. } \\
\text { Results of this study showed that survival percent, sprout length, leaf area, collar diameter, } \\
\text { root diameter, root length and number of lateral roots were significantly affected by the } \\
\text { root pruning treatments. However, no-significance differences of poplar clones were } \\
\text { observed on survival percent, sprout length, root length and number of lateral roots. The } \\
\text { roots pruned at } 5 \mathrm{~cm} \text { gave the best result for growth and development of poplar clones } \\
\text { whereas the roots pruned at } 20 \mathrm{~cm} \text { length showed the lowest values. }\end{array}$} \\
\hline Article Info & \\
\hline $\begin{array}{l}\text { Accepted: } \\
\text { 15 March } 2017 \\
\text { Available Online: } \\
\text { 10 April } 2017\end{array}$ & \\
\hline
\end{tabular}

\section{Introduction}

The fast growing tree species of choice belong to genus Populus which belongs to family Salicaceae.To fulfill the increasing demand for forest products, fast-growing trees such as poplar are grown on the managed plantations and are being seriously considered for future supply needs. Poplars are widely grown for its multipurpose uses. Populus includes the specie eastern cottonwood ( $P$. deltoides) often characterized as fast-growing, moisture-loving, and shade-intolerant medium to large trees with a short life span. Cottonwood can be naturally regenerated usually by seeds. They can be also propagated by the usual of vegetative reproduction. They mostly occur in the low lying moist alluvial grounds tolerate flooding for a short time during the rainy season and can be propagated vegetatively. Poplars are one of the most easily cloned woody species, which allows for greater availability of promising crosses. Numerous methods are available for regulating vegetative growth in deciduous tree species (Miller and Tworkoski, 2003). It has been used as a horticultural practice to produce sturdier trees, force development of a more compact fibrous root system, retard top growth and increase transplant survival and post transplant growth (Mullin, 1988). Root systems with numerous laterals roots are one of the most essential attributes of high quality seedlings (Aldhus, 1994). Moreover, the form 
of root development of seedlings largely affects the plantation performance (Sutton, 1980; Burdett et al., 1983). Transplanting container grown stock with undesirable root form results in poor establishment (Struve, 1993) and reduced shoot growth (Arnold et al., 1993). Root pruning is often required to correct root malformation of container grown plants before transplanting. Root pruning increases secondary root branching, reduce root circling and promote root regeneration after transplanting (Arnold and Struve, 1993; Arduini et al., 1995; Crawford, 1997).

Root pruning is the common practice of removing small portion of a tree's root system (Gazal et al., 2004). Root pruning in fruit, forest and landscape tree nurseries is an old and varied practice (Hawley and Smith 1998). Root pruning is a common technique that can reduce vegetative growth of apple trees (Geisler and Ferree, 1984; Asin et al., 2007) which help in dwarfing and also helps to stimulate the new roots necessary to carry on growth. To be precise, root pruning destroyed the old growth balances of trees and changed their assimilation abilities, nutrient distributions and hormone levels. Root pruning is also reported to be used easier for planting the seedlings of Loblolly pine seedlings (Dierauf and Garner, 1978). The main aim of this practice is to manage the tree and crops competition for resources, reduce the vegetative and reproductive growth of fruit trees under an ultra high density planting system (Khan et al., 1998) and a well developed or well structured root systems with numerous lateral roots, which are one of the most essential attributes of high quality seedlings (Aldhus, 1994; Asin et al., 2007). However, no research is available on the effects of root pruning on the morphological growth of poplar trees. The objective of this paper is to determine the effect of root pruning at different length on the plant survival, sprout length, collar diameter, leaf area, root diameter, root length and number of lateral roots.

\section{Materials and Methods}

The field experiment was initiated at Forest Nursery, College of Forestry, Allahabad, Sam Higginbottom University of Agriculture, Technology and Sciences Allahabad in 2012 to 2013 find out the best root pruning length of $\mathrm{S}_{7} \mathrm{C}_{15}$ and Uday clones of Populus deltoides. The site was located at 258' latitude and $81^{\circ} 58^{\prime}$ ' longitude at an elevation of $98 \mathrm{~m}$ above msl., shoots of 10 year old tree were used for making the cuttings of uniform length. The cuttings were planted in the polybags keeping one or two buds above the soil. Each cutting was gently placed without injuring the buds in the polybags during the month of February and was kept in the green house for 5 months. Ten cuttings under each treatment i.e. $\mathrm{T}_{1}$ un-pruned (control), $\mathrm{T}_{2}$ root pruned at $5 \mathrm{~cm}, \mathrm{~T}_{3}$ root pruned at $10 \mathrm{~cm}$, $\mathrm{T}_{4}$ root pruned at $15 \mathrm{~cm}, \mathrm{~T}_{5}$ root pruned at 20 $\mathrm{cm}$ for each clone were taken. Later the root plants were transplanted into already prepared nursery beds on the onset of monsoon i.e., mid July. A distance of $40 \mathrm{~cm}$ was maintained between the cuttings while the row to row distance was kept $45 \mathrm{~cm}$. The treated plants were managed in accordance to the routine methods and irrigation was provided at a regular interval. Five root pruning treatments were applied to examine the plants.

\section{P $\mathrm{P}_{1}$ - un-pruned(Control) \\ 2. $\mathrm{P}_{2}$ - root pruned at $5 \mathrm{~cm}$ \\ 3. $P_{3}$ - root pruned at $10 \mathrm{~cm}$ \\ 4. $\mathrm{P}_{4}$ - root pruned at $15 \mathrm{~cm}$ \\ $5 . \mathrm{P}_{5}$ - root pruned at $20 \mathrm{~cm}$}

The experiment involved a factorial randomized block design with five treatments and three replications. The observations recorded for the above ground growth parameters during the study were survival 
percentage, sprout height, leaf area and collar diameter whereas, for the below ground developments the observations taken were root diameter, root length and number of lateral roots were measured and counted, respectively.

\section{Results and Discussion}

Analyzing the data from tables 1 and 2 it can be found that root pruning treatments had an important influence on the vegetative growth of Poplar (Populus deltoides) clones.

\section{Survival percentage (\%)}

Significant difference was found among the root pruning treatments whereas the clones showed that there was no significant difference between the clones. Survival percentage was recorded highest in treatment $\mathrm{T}_{2}(76.66 \%)$ for $\mathrm{S}_{7} \mathrm{C}_{15}$ and (66.66\%) Uday, respectively.

\section{Sprout length $(\mathrm{cm})$}

Sprout length $(\mathrm{cm})$ observed the highest values of $(77.3 \mathrm{~cm})$ and $(75.8 \mathrm{~cm})$ for poplar clones $\mathrm{S}_{7} \mathrm{C}_{15}$ and Uday respectively in treatment $\mathrm{T}_{2}$ (root pruning done at $5 \mathrm{~cm}$ ) and confirms to have a highly significant variation. The clones of poplar $\mathrm{S}_{7} \mathrm{C}_{15}$ and Uday were found non-significant during the study period. The interaction between the different root pruning treatments and the clones of poplars were found highly significant.

Table.1 Effect of root pruning treatments on above ground growth development of poplar (Populus deltoides) clones

\begin{tabular}{|c|c|c|c|c|c|c|c|c|c|c|c|c|}
\hline \multirow[t]{2}{*}{ Treatment } & \multicolumn{3}{|c|}{ Survival percent (\%) } & \multicolumn{3}{|c|}{ Sprout length $(\mathrm{cm})$} & \multicolumn{3}{|c|}{ Leaf Area $(\mathrm{cm} 2)$} & \multicolumn{3}{|c|}{ Collar Diameter (mm) } \\
\hline & $\mathrm{C}_{1}$ & $\mathrm{C}_{2}$ & Mean & $C_{1}$ & $\mathrm{C}_{2}$ & Mean & $\mathrm{C}_{1}$ & $\mathrm{C}_{2}$ & Mean & $\mathrm{C}_{1}$ & $\mathrm{C}_{2}$ & Mean \\
\hline $\begin{array}{c}\mathrm{T}_{1} \\
\text { Un-pruned }\end{array}$ & 70.00 & 63.33 & 66.67 & 67.2 & 65.3 & 66.25 & 166.66 & 157.77 & 162.22 & 4.14 & 3.88 & 4.01 \\
\hline $\begin{array}{c}\mathrm{T}_{2} \\
\text { (Root Pruned } \\
\text { at } 5 \mathrm{~cm} \text { ) }\end{array}$ & 76.66 & 66.66 & 71.66 & 77.3 & 75.8 & 76.55 & 183.46 & 174.00 & 178.73 & 4.98 & 4.43 & 4.71 \\
\hline $\begin{array}{c}\mathrm{T}_{3} \\
\text { (Root Pruned } \\
\text { at } 10 \mathrm{~cm} \text { ) }\end{array}$ & 73.33 & 60.00 & 66.67 & 75.4 & 74.2 & 74.8 & 158.9 & 142.00 & 150.45 & 4.20 & 3.93 & 4.07 \\
\hline $\begin{array}{c}\mathrm{T}_{4} \\
\text { (Root Pruned } \\
\text { at } 15 \mathrm{~cm} \text { ) }\end{array}$ & 63.00 & 56.66 & 59.83 & 71.4 & 68.9 & 70.15 & 132.67 & 120.44 & 126.56 & 3.48 & 3.18 & 3.33 \\
\hline $\begin{array}{c}\mathrm{T}_{5} \\
\text { (Root Pruned } \\
\text { at } 20 \mathrm{~cm} \text { ) }\end{array}$ & 50.00 & 47.00 & 48.50 & 66.8 & 64.3 & 65.55 & 100.21 & 98.77 & 99.49 & 2.89 & 2.54 & 2.72 \\
\hline Mean & 66.59 & 58.73 & & 71.6 & 69.7 & & 148.38 & 138.59 & & 3.94 & 3.59 & \\
\hline & C.D & $\operatorname{SE}(d)$ & $\begin{array}{c}\text { F- } \\
\text { Test }\end{array}$ & C.D & $\operatorname{SE}(d)$ & $\begin{array}{c}\text { F- } \\
\text { Test }\end{array}$ & C.D & $\mathrm{SE}(\mathrm{d})$ & F-Test & C.D & $\mathrm{SE}(\mathrm{d})$ & $\begin{array}{c}\text { F- } \\
\text { Test }\end{array}$ \\
\hline Treatment & 6.939 & 3.27 & $\mathrm{~S}$ & 0.994 & 0.47 & $\mathrm{~S}$ & 5.132 & 2.424 & $\mathrm{~S}$ & 0.434 & 0.205 & $\mathrm{~S}$ \\
\hline Clone & - & 2.07 & NS & - & 0.297 & $\mathrm{NS}$ & 3.246 & 1.533 & $S$ & 0.275 & 0.13 & $S$ \\
\hline $\begin{array}{c}\text { Interaction } \\
(\mathrm{TXC})\end{array}$ & - & 4.635 & NS & 1.406 & 0.662 & S & 7.258 & 3.428 & $S$ & 0.614 & 0.29 & $S$ \\
\hline
\end{tabular}


Table.2 Effect of root pruning on below ground growth development of Poplar (Populus deltoides) clones

\begin{tabular}{|c|c|c|c|c|c|c|c|c|c|}
\hline \multirow[t]{2}{*}{ Treatment } & \multicolumn{3}{|c|}{ Root diameter $(\mathrm{mm})$} & \multicolumn{3}{|c|}{ Root length (cm) } & \multicolumn{3}{|c|}{ Number of lateral roots } \\
\hline & $\mathrm{C}_{1}$ & $\mathrm{C}_{2}$ & Mean & $\mathbf{C}_{1}$ & $\mathrm{C}_{2}$ & Mean & $\mathbf{C}_{1}$ & $\mathrm{C}_{2}$ & Mean \\
\hline $\begin{array}{c}\mathrm{T}_{1} \\
\text { Un-pruned }\end{array}$ & 3.12 & 2.84 & 2.98 & 42.0 & 40.4 & 41.2 & 12.0 & 11.00 & 11.50 \\
\hline $\begin{array}{c}\mathrm{T}_{2} \\
\text { (Root Pruned at } 5 \\
\mathrm{~cm} \text { ) }\end{array}$ & 3.62 & 3.33 & 3.48 & 48.5 & 47.2 & 47.85 & 15.30 & 14.33 & 14.83 \\
\hline $\begin{array}{c}\mathrm{T}_{3} \\
\text { (Root Pruned at } 10 \\
\mathrm{~cm} \text { ) }\end{array}$ & 3.58 & 3.21 & 3.40 & 46.4 & 45.2 & 45.8 & 14.20 & 13.26 & 13.76 \\
\hline $\begin{array}{c}\mathrm{T}_{4} \\
\text { (Root Pruned at } 15 \\
\mathrm{~cm} \text { ) }\end{array}$ & 3.33 & 2.68 & 3.01 & 43.4 & 42.5 & 42.95 & 13.00 & 12.66 & 12.83 \\
\hline $\begin{array}{c}\mathrm{T}_{5} \\
\text { (Root Pruned at } 20 \\
\mathrm{~cm} \text { ) }\end{array}$ & 2.96 & 2.22 & 2.59 & 38.0 & 37.2 & 37.6 & 8.60 & 6.20 & 7.40 \\
\hline \multirow[t]{2}{*}{ Mean } & 3.32 & 2.85 & & 43.6 & 42.5 & & 12.64 & 11.49 & \\
\hline & C.D & $\operatorname{SE}(d)$ & F-Test & C.D & $\operatorname{SE}(d)$ & F-Test & C.D & $\operatorname{SE}(d)$ & F-Test \\
\hline Treatment & 0.200 & 0.094 & $S$ & 1.427 & 0.674 & $S$ & 0.894 & 0.422 & $S$ \\
\hline Clone & 0.126 & 0.06 & $S$ & - & 0.426 & NS & - & 0.267 & NS \\
\hline Interaction (TXC) & 0.238 & 0.134 & $\mathrm{~S}$ & 2.018 & 0.953 & $\mathrm{~S}$ & 1.264 & 0.597 & $\mathrm{~S}$ \\
\hline
\end{tabular}

\section{Leaf area $\left(\mathrm{cm}^{2}\right)$}

Root pruning treatment on leaf area had a highly significant variation during the year of experiment. The highest leaf area was recorded for treatment $\mathrm{T}_{2}\left(183.46 \mathrm{~cm}^{2}\right)$ and $\left(174 \mathrm{~cm}^{2}\right)$ for $\mathrm{S}_{7} \mathrm{C}_{15}$ and Uday. The poplar clones were found significant during the experiment. The interaction between the treatments and clones of poplar were observed highly significant from each other.

\section{Collar diameter (mm)}

It is clearly indicated that root pruning treatments had a highly significant variation on the collar diameter of poplar. The clones of poplar were also found to be highly significant. The highest collar diameter was recorded in $\mathrm{T}_{2}$ (root pruned at $5 \mathrm{~cm}$ ) $(4.98 \mathrm{~mm})$ for $\mathrm{S}_{7} \mathrm{C}_{15}$ and $(4.43 \mathrm{~mm})$ for Uday clones of poplar which were significantly followed by $\mathrm{T}_{3}$ and $\mathrm{T}_{4}$, whereas the lowest collar diameter was found in $\mathrm{T}_{5}(2.89 \mathrm{~mm})$ for $\mathrm{S}_{7} \mathrm{C}_{15}$ and for Uday $(2.54 \mathrm{~mm})$ respectively. The interaction between the treatments and clones of poplar were found highly significant. Collar diameter increased by decreasing the length of the pruning (Pourmajidian et al., 2009). 
In conclusion, roots play an important role which helps in uptake of water and nutrients. Root pruning helps to develop new roots when grown in ideal climatic conditions. Root pruning is main practice used in the nurseries for seedlings and young plants growing in soil beds in amenity and forest trees nurseries. Results of this study reveals that survival percent, sprout length, leaf area, collar diameter, root diameter, root length and number of lateral roots were increased by decreasing the length of root pruning, further study suggested that root pruning done at 5 $\mathrm{cm}$ should be selected for the better growth and development of poplar clones.

\section{Acknowledgements}

The authors would like to thank the College of Forestry, Allahabad, Sam Higginbottom University of Agriculture, Technology and Sciences, Allahabad for facilitating this experiment.

\section{References}

Aldhus, J.R. 1994. Nursery policy and planning. Forest Nursery Practice, vol.111. Forestry Commission Bull., pp $1-12$.

Arduini, I., Godbold, D.L., Onnis, A. 1995. Influence of copper on root growth and morphology of Pinuspinea L. and Pinuspinaster Ait. seedlings. Tree Physiol., 15: 411-415.

Arnold, M.A., Struve, D.K. 1993. Root distribution and mineral uptake of coarse-rooted trees grown in cuprichydroxide treated containers. Hort Sci., 28: 988-992.

Asin, L., Alegre, S., Montserrat, R. 2007. Effect of paclobutrazol, prohexadioneCa. deficit irrigation, summer pruning and root pruning on the shoot growth, yield and return bloom in a Blanquilla pear orchard. Scientia Horticulturae,
113: pp 142-148.

Burdett, A.N., Simpson, D.G., Thompson, C.F. 1983. Root development and plantation establishment success. Plant Soil, 71: 103-110.

Crawford, M.A. 1997. Update on copper root control. In: Landis, T.D., Thompson, J.R. (Eds.), National Proceedings, Forest and Conservation Nursery Associations. USDA Forest Service, Gen. Tech. Rep. PNWGTR- 419, Pacific Northwest Research Station, Portland, pp. 120-124

Dierauf, T.A. and Garner, J.W. 1978. Root pruning Loblolly pine seedlings effect on survival and growth. Occasional Report, 52: 1-4.

Farmer, J.W. and Pezeshki S.R. 2004. Effect of periodic flooding and root pruning on Quercusnuttallii seedling. Wetlands Ecol. Manage., 12: 205-214.

Gazal, R.M., Blanche, C.A., Carandang, W.M. 2004. Root growth potential and seedling morphological attributes of narra (Pterocarpusindicus Willd.) transplants. Forest Ecol. Manage., 195: pp. 259-266.

Geisler, D., Ferree, D.C. 1984. The influence of root pruning and water relation, net photosynthesis, and growth of young golden delicious apple tree. J. American Soc. Horticultural Sci., 109: 827-831.

Geisler, D., Feree, D.C. 1984. Response of plants to root pruning. Horticultural Rev., 6: 155-188.

Gilman, E.F. 1992. Effect of root pruning prior to transplanting on establishment of Southern magnolia in the landscape. J. Arboriculture, 18: 197-200.

Grim, G.R. 1956. Preliminary investigations on dieback of young transplanted citrus trees. Proceedings of the Florida State Horticultural Society, 69: 31-34.

Hawley, R.C., Smith, D.M. 1954. The Practice of Silviculture (6th Edn), John Wiley and Sons, NY, 525 pp. 
Khan, Z.U., McNeil, D.L. and Samad, A. 1998. Root pruning reduces the vegetative and reproductive growth of apple trees growing under an ultra high density planting system. Scientia Horticulturae, 77: 165-176.

Maggs, D.H. 1964. Growth rates in relation to assimilate supply and demand I. Leaves and roots as limiting regions. $J$. Experimental Botany, 15: 574-583.

Miller, S. and Tworkoski, T. 2003. Regulating vegetative growth in deciduous fruit trees. Quarterly Reports on Plant Regulation and Activities of the PGRSA, 1: 8-46.

Mullin, R.D. 1988. Root pruning of nursery stock. Forest Chronicle, 42: 256-264.

Richards, D., R.N. Rowe. 1977. Root shoot interactions in peach. The function of the root. Annals of Botany, 41: 1211-
1216.

Schupp, J.R. and Ferree, D.C. 1988. Effects of root pruning at four levels of severity on growth and yield of Melrose/M. 26. J. Amer. Soc. Hort. Sci., 113: 194-198.

Schupp, J.R. and Ferree, D.C. 1987. Effects of root pruning at different growth stages on growth and fruiting of apple trees. Hort. Sci., 22: 387-390.

Struve, D.K. 1993. Effect of copper-treated containers on transplant survival and regrowth of four tree species. J. Environ. Hort., 11: 196-199.

Sutton, R.F. 1980. Planting stock quality, root growth capacity and field performance of three boreal conifers. N. Z. J. Sci., 10: 54-71.

Wilcox, H. 1995. Regeneration of injured root systems of noble fir. Botanical Gazette, 116: $221-228$.

\section{How to cite this article:}

Neeta Shweta Kerketta, Afaq MajidWani, Sameer Daniel and Hemant Kumar. 2017. Influence of Root Pruning on Stem and Root Morphology of Poplar (Populus deltoides) Clones. Int.J.Curr.Microbiol.App.Sci. 6(4): 1482-1487. doi: https://doi.org/10.20546/ijcmas.2017.604.181 